\title{
Progress report on development of classification criteria for adult and juvenile idiopathic inflammatory myopathies
}

\author{
Clarissa Pilkington ${ }^{1,2^{*}}$, Anna Tjärnlund ${ }^{3}$, Matteo Bottai ${ }^{4}$, Victoria Werth ${ }^{5}$, Marianne de Visser ${ }^{6}$, Lars Alfredsson $^{7}$, \\ Anthony Amato ${ }^{8}$, Richard J Barohn ${ }^{9}$, Matthew Liang ${ }^{10}$, Jasvinder Singh ${ }^{11}$, Frederick W Miller ${ }^{12}$, Lisa Rider ${ }^{12}$, \\ Ingrid E Lundberg ${ }^{3}$, the members of the International Myositis Classification Criteria Project
}

From 21st European Pediatric Rheumatology (PReS) Congress

Belgrade, Serbia. 17-21 September 2014

\section{Introduction}

Classification criteria are needed to aid recruitment of appropriate patients into research studies. The International Myositis Classification Criteria Project (IMCCP) was set up with support from ACR and EULAR.

\section{Objectives}

To develop and validate new classification criteria for adult and juvenile IIM.

\section{Methods}

Candidate criteria variables were taken from published criteria and inclusion criteria from clinical trials of myositis. Comparator groups confused with IIM were defined. Clinical and laboratory data from IIM and comparator patients were collected from 47 rheumatology, dermatology, neurology and pediatrics clinics worldwide from 2008-2011.
Pair-wise associations among all items and between each item and clinicians' diagnoses were assessed. Three approaches for derivation of classification criteria were explored: Traditional, Probability score and Classification tree.

Internal validation using bootstrap methods and external validation using data from the Euromyositis register and the Juvenile Dermatomyositis cohort biomarker study and repository UK and Ireland was performed.

\section{Results}

976 IIM (74\% adults; $26 \%$ children) and 624 comparators (81\% adults; $19 \%$ children) were obtained.

The new criteria comprise clinical items on muscles, skin, and laboratory measures. Muscle biopsy features can be included. Each item has an assigned score, the total score corresponds to the probability of having IIM.

Table 1 Performance of new and exisiting classification / diagnostic criteria for idiopathic inflammatory myopathies

\begin{tabular}{|c|c|c|c|c|c|c|c|}
\hline \multirow{2}{*}{$\begin{array}{l}\text { Performance } \\
\text { (\%) }\end{array}$} & \multicolumn{2}{|c|}{ New classification criteria $^{a}$} & \multirow{2}{*}{$\begin{array}{c}\text { Peter \& Bohan } \\
{[1]^{\mathrm{b}}}\end{array}$} & \multirow{2}{*}{$\begin{array}{c}\text { Tanimoto et } \\
\text { al. [2] }\end{array}$} & \multirow{2}{*}{$\begin{array}{l}\text { Targoff et al. } \\
{[3]^{b}}\end{array}$} & \multirow{2}{*}{$\begin{array}{c}\text { Dalakas \& } \\
\text { Hohlfeld }[4]^{b}\end{array}$} & \multirow{2}{*}{$\begin{array}{l}\text { Hoogendijk et al } \\
{[5]^{b}}\end{array}$} \\
\hline & $\begin{array}{c}\text { Without muscle biopsy } \\
\text { data }\end{array}$ & $\begin{array}{c}\text { With muscle biopsy } \\
\text { data }\end{array}$ & & & & & \\
\hline Sensitivity & 91 & 94 & 98 & 96 & 93 & 6 & 51 \\
\hline Specificity & 82 & 85 & 55 & 31 & 88 & 99 & 96 \\
\hline $\begin{array}{l}\text { Correctly } \\
\text { classified }\end{array}$ & 88 & 91 & 86 & 79 & 91 & 45 & 70 \\
\hline
\end{tabular}

${ }^{a}$ Cut point for probability: $55 \%$

${ }^{\mathrm{b}}$ Definite and probable polymyositis and dermatomyositis

${ }^{1}$ Rheumatology, Institute of Child Health, UK

Full list of author information is available at the end of the article

(c) 2014 Pilkington et al; licensee BioMed Central Ltd. This is an Open Access article distributed under the terms of the Creative Commons Attribution License (http://creativecommons.org/licenses/by/4.0), which permits unrestricted use, distribution, and 
Each probability has specific sensitivity/specificity measures making it possible to use individual inclusion criteria for clinical studies. If no skin rash is present a muscle biopsy is mandatory. High probability of IIM is considered if the score $>7.5$ (or $>8.7$ if no skin rash), with minimum probability cutoff of $50 \%$ (score 5.3 or 6.5). Table 1.

External validation using data on 592 adult or 332 juvenile IIM patients yielded 100\% sensitivity.

\section{Conclusion}

The new classification criteria for IIM have easy-toaccess items and show generally superior performance compared to existing criteria. Approval for these will be sought from ACR/EULAR.

\section{Disclosure of interest}

None declared.

\section{Authors' details}

${ }^{1}$ Rheumatology, Institute of Child Health, UK. ${ }^{2}$ Rheumatology, Great Ormond Street Hospital, London, UK. ${ }^{3}$ Rheumatology, Karolinska University Hospital, Karolinska Institue, Sweden. ${ }^{4}$ Institute for Environmental Medicine, Karolinska Institue, Stockholm, Sweden. ${ }^{5}$ Dermatology, Philadelphia VAMC and Hospital of the University of Pennsylvania, Philadelphia, USA. ${ }^{6}$ Neurology, Academic Medical Centre, Amsterdam, Netherlands. ${ }^{7}$ Institute for Environmental Medicine, Karolinska Institue, Stockholm, Sweden. ${ }^{8}$ Neurology, Brigham and Women's Hospital, Boston, USA. ${ }^{9}$ Neurology, University of Kansas Medical Center, Kansas City, USA. ${ }^{10}$ Rheumatology, Immunology and Allergy, Brigham and Women's Hospital, Boston, USA. ${ }^{11}$ University of Alabama and VA Medical Center, Birmingham, AL, USA. ${ }^{12}$ Environmental Autoimmunity Group, Program of Clinical Research, National Institute of Environmental Health Sciences, National Institutes of Health, US Department of Health and Human Services, Bethesda, USA.

Published: 17 September 2014

\section{Submit your next manuscript to BioMed Central} and take full advantage of:

- Convenient online submission

- Thorough peer review

- No space constraints or color figure charges

- Immediate publication on acceptance

- Inclusion in PubMed, CAS, Scopus and Google Scholar

- Research which is freely available for redistribution

Submit your manuscript at www.biomedcentral.com/submit 